CODEN : $A M M C F L$

\title{
THEORETICAL ASPECT IN FORMULATING ASSESSMENT MODEL OF BIG DATA ANALYTICS ENVIRONMENT
}

Cecilia Adrian, Rusli Abdullah, Rodziah Atan, Yusmadi Yah Jusoh

Department of Software Engineering and Information Systems, Faculty of Computer Science and Information Technology, Universiti Putra Malaysia

*Corresponding Author Email: cecilia.upm@gmail.com, \{rusli, rodziah, yusmadi\}@upm.edu.my

This is an open access article distributed under the Creative Commons Attribution License, which permits unrestricted use, distribution, and reproduction in any medium, provided the original work is properly cited.

\section{ARTICLE DETAILS}

\section{Article History:}

Received 10 December 2017

Accepted 08 January 2018

Available online 19 February 2018

\section{ABSTRACT}

This paper explains the interrelationship of organization, people and technology dimensions were considered in formulating the big data analytics (BDA) environment assessment model. The theoretical lenses used in the model development are included Resource-based View (RBV) and Information Systems Success Model (ISSM).

\section{KEYWORDS}

Big data analytics, assessment model, RBV and ISSM.

\section{INTRODUCTION}

The usage of data analytics in decision-making has created new potential insights for business opportunities. The advancement of BDA has benefited various large organizations in enhancing the organizational performance. However, the big data phenomenon is not about having a massive, speedy and varieties of data, but its required proper implementation plan and financial investment for additional and relevant resources. Lacking assessment towards the existing resources may af-fect the BDA implementation and operational activities. Therefore, in assisting the business lead-ers and decision-makers, there is a need to assess the impact of the BDA environment in enhancing the decision-making and organizational performance. The assessment is included in many aspects such as the organizational capabilities, big data resources and quality of information. It is hoped that the assessment may benefit the organization for effective strategy and alignment of the current need. The objective of this paper is to formulate the theoretical aspects to be considered in the development of the BDA assessment model.

In achieving the paper's objective, we followed the systematic literature review guidelines and performed content analysis [1]. The formulation of the research model is carried out based on five steps. The first step is formulating a research question such as "What are the factors to be considered in formulating an assessment BDA model?', then followed by the second step is conducting search documents from electronic databases and review the selected papers. The third step includes listing the factors to be considered in formulating the assessment model. The next step is analyzing the factors and summarize in the matrix table. The fifth step is designing the conceptual assessment model for the big data environment. The output of these steps is the interrelationship of BDA components and theoretical aspects as shown in Figure 1.

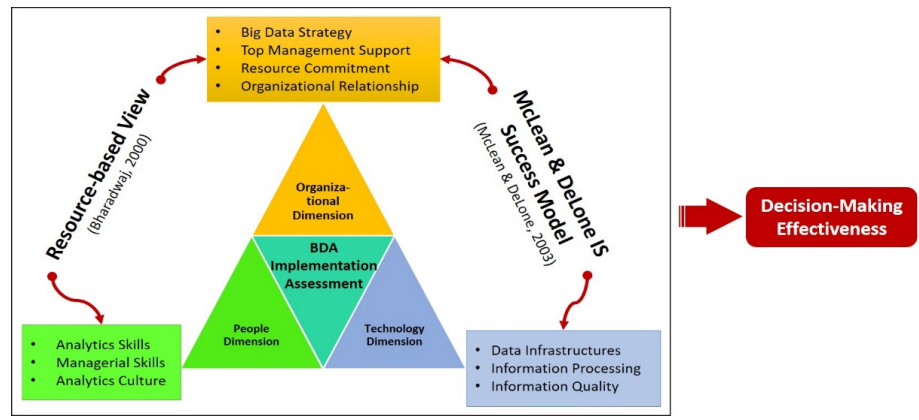

Figure 1: Interrelationship of theoretical aspects and assessment components of its model

\section{RESULTS AND DISCUSSION}

In developing the BDA assessment model, we have suggested three important dimensions to be considered such as organizational, people and technology. The components of organizational di-mension are including big data analytics strategy, top management support, resource commitment and organizational relationship [2-7]. Meanwhile, the people components are consisting of the analytics skills, managerial skills and analytics cultures [6-8]. The components of technology di-mension are including data infrastructures, information processing and information quality $[6,7,9]$. The implementation of BDA in the organization can be involved many theories to be apply. Nevertheless, the model in Figure 1 is very closed to the adoption of Resource-based View theory (RBV) by Bharadwaj and the updated Information Systems Success Model (ISSM) by McLean and DeLone $[10,11]$. The justification of theory's application to BDA assessment model is dis-cussed in Table 1.

Table 1: Theory, descriptions and its application to BDA environment assessment model

\begin{tabular}{|l|l|l|}
\hline \multicolumn{1}{|c|}{ Theory } & \multicolumn{1}{|c|}{ Descriptions } & \multicolumn{1}{c|}{$\begin{array}{c}\text { Application of Big Data Analytics } \\
\text { Assessment Model }\end{array}$} \\
\hline $\begin{array}{l}\text { Resource- } \\
\text { based View } \\
\text { (RBV) }\end{array}$ & $\begin{array}{l}\text { The theory considers organization } \\
\text { as a collection of tangible and in- } \\
\text { tangible resources and capabilities } \\
\text { to achieve competitive advantages } \\
\text { and organizational performance. }\end{array}$ & $\begin{array}{l}\text { The theory was used to justify and under- } \\
\text { stand the relative contribution of re- } \\
\text { sources availability and capability in- } \\
\text { volving organizational features, people } \\
\text { skills and enabler technology, towards } \\
\text { the diffusion of BDA implementation for } \\
\text { effective decision-making. }\end{array}$ \\
\hline $\begin{array}{l}\text { Information } \\
\text { Systems Suc- } \\
\text { cess Model } \\
\text { (ISSM) }\end{array}$ & $\begin{array}{l}\text { The model provides a foundation } \\
\text { to understand the information, sys- } \\
\text { tem and service quality that have } \\
\text { impact to organizational perfor- } \\
\text { mance. }\end{array}$ & $\begin{array}{l}\text { The theory was used to justify and under- } \\
\text { stand the quality of big data analytics re- } \\
\text { sults (i.e. information quality) towards } \\
\text { effective decision-making. }\end{array}$ \\
\hline
\end{tabular}

\section{CONCLUSION}

The development of the BDA assessment model may have benefited to organizational manage-ment in resources planning and monitoring towards effective decision-making. In this study, the theoretical lenses such as RBV and ISSM are applied in formulating the BDA environment assess-ment model and considering the interrelationship of theoretical aspects of the organization, people and technology dimensions.

\section{REFERENCES}

[1] Okoli, C., Schabram, K. 2010. A Guide to Conducting a Systematic Literature Review of In-formation Systems Research. Sprouts Work. Pap. Inf. Syst., 10 (26), 1-51. 
[2] Cao, G., Duan, Y., Li, G. 2015. Linking Business Analytics to Decision Making Effectiveness: A Path Model Analysis. IEEE Transactions on Engineering Management, 62 (3), 384-395.

[3] Wren, G.P., Hoskisson, A. 2015. An analytical journey towards big data. Journal of Decision Systems, 125 (6), 1-16.

[4] Kulkarni, U.R., Flores, J.A.R., Popovič, A. 2017. Business Intelligence Capability: The Effect of Top Management and the Mediating Roles of User Participation and Analytical Decision-Mak-ing Orientation. Journal of the Association for Information Systems, 18 (7), 516-541.

[5] Mao, H., Liu, S., Zhang, J., Deng, Z. 2016. Information technology resource, knowledge man-agement capability, and competitive advantage: The moderating role of resource commitment. In-ternational Journal of Information Management, 36 (6), 1062-1074.

[6] Wamba, S.F., Gunasekaran, A., Akter, S., Ren, S.J., Dubey, R., Childe, S.J. 2016. Big data analytics and firm performance: Effects of dynamic capabilities. Journal of Business Research, 70, 356-365.
[7] Akter, S., Wamba, S.F., Gunasekaran, A., Dubey, R., Childe, S.J. 2016. How to improve firm performance using big data analytics capability and business strategy alignment. International Journal of Production Economics, 182, 113-131.

[8] Gupta, M., George, J.F. 2016. Toward the Development of a Big Data Analytics Capability. Information and Management, 53 (8), 1046-1064.

[9] Ren, S.J.F., Wamba, S.F., Akter, S., Dubey, R., Childe, S.J. 2016. Modelling quality dynamics, business value and firm performance in a big data analytics environment. International Journal of Production Research, 116.

[10] Bharadwaj, A.S. 2000. A Resource-Based Perspective on Information Technology Capability and Firm Performance: An Empirical Investigation. MIS Q., 24 (1), 169-196.

[11] DeLone, W.H., McLean, E.R. 2003. The DeLone and McLean model of information system success. Journal of Management Information Systems, 19, 9-30. 